\title{
Human Health Risks of Heavy Metal in Wells and Streams Water in the Vicinity of a Lead Mining in Nasarawa State, North Central, Nigeria
}

\author{
Musa Williams Ombuguss, *, Wuana Raymond Ahulle², Itodo Udoji Adams², Eneji Ishaq Shaibu \\ ${ }^{1}$ Chemistry Department, College of Education, Akwanga, Nasarawa State, Nigeria \\ ${ }^{2}$ Department of Chemistry and Centre for Agrochemical Technology and Environmental Research, Federal University of Agriculture \\ Makurdi, Benue State, Nigeria
}

\author{
Email address: \\ browilliams70@gmail (M. W. Ombugus), raynewton73@gmail.com (W. R. Ahulle), itodoau@uam.edu.ng (I. U. Adams), \\ Ishaqeneji@gmail.com (E. I. Shaibu) \\ ${ }^{*}$ Corresponding author
}

\section{To cite this article:}

Musa Williams Ombugus, Wuana Raymond Ahulle, Itodo Udoji Adams, Eneji Ishaq Shaibu. Human Health Risks of Heavy Metal in Wells and Streams Water in the Vicinity of a Lead Mining in Nasarawa State, North Central, Nigeria. Journal of Health and Environmental Research. Vol. 7, No. 2, 2021, pp. 76-87. doi: 10.11648/j.jher.20210702.11

Received: March 10, 2021; Accepted: March 23, 2021; Published: April 7, 2021

\begin{abstract}
The quality of surface and ground water in mining communities is uncertain since metals associated with acid mine drainage are known to saturate these waters. A total of two (2) hand dug wells, two (2) stream water and six (6) mine waste water samples were collected in March 2019. The water samples were analyzed in triplicate for $\mathrm{As}, \mathrm{Pb}, \mathrm{Hg}, \mathrm{Cu}, \mathrm{Zn}, \mathrm{Ni}$, $\mathrm{Cr}$ and $\mathrm{Cd}$ using AAS. The toxic metals concentration sequence was such that $\mathrm{Pb}>\mathrm{Zn}>\mathrm{Cu}>\mathrm{Cd}>\mathrm{Cr}>\mathrm{Ni}>\mathrm{Hg}>\mathrm{As}$. $\mathrm{Pb}, \mathrm{Cd}$ and $\mathrm{Cr}$ concentrations were higher than WHO and NESREA Standard limits. Measured concentrations of these heavy metals were used to calculate the health risk for human population. The Hazard Index (HI) value for all pathways was found to be 236.8 in mine waste water, 23.39 in stream water $1,12.91$ in stream water 2, 11.1 in well water 1 and 45.07 in well water 2. Among all the studied metals, $\mathrm{Cr}$ and $\mathrm{Cd}$ has the highest chances of cancer risks with ILCR values of $1.8 \times 10^{-3}$ and $5.17 \times 10^{-3}$ while $\mathrm{Pb}$ and $\mathrm{Ni}$ has the lowest chances of cancer risks with ILCR values of $1.69 \times 10^{-4}$ and $5.9 \times 10^{-4}$.
\end{abstract}

Keywords: Heavy Metal, Water Quality, Health Risk, Mining, Assessment

\section{Introduction}

Water quality is important for health and economic development of every Nation [1, 2]. Meanwhile, it is not accessible to a large number of population in the recommended quality [3]. However, stream and river water bodies are quite vulnerable to pollution because they are naturally open, easily accessible, and substantially used in agricultural, industrial, and municipal process [4]. Heavy metal interactions between ground water and surface water bodies are complex and may be influenced by various factors such as topography, geology, climate and the position of the surface water body relative to the ground water flow systems $[5,3]$. Shallow groundwater (hand-dug well), surface waters (rivers, streams and ponds) and rain-water are the main sources of water available to the rural dwellers in Nigeria [6,
7]. Heavy metals contaminate surface and ground water, resulting in deterioration of drinking water and irrigation water quality and can enter into the human food chain, posing a risk to human health [8].

Meanwhile, rapid industrialization and intensive anthropogenic activities have already brought and will continue to bring a series of water pollution around the world $[6,9]$. Heavy metals contaminations are subject to environmental toxicity, abundance, and persistence, the contamination by these metals in the aquatic environment becomes a global concern [10]. In year 2010, accelerating exploitation of numerous mines in Northwestern Nigeria has brought many environmental problems, especially the contamination of farmland and various water sources caused by an overdose of dissolved lead metals with major accidents, killing mostly children, and that has attracted 
nationwide and international attention [11-13]. Mining activity produces waste water, and this wastes from mining processes, can result in the influx of heavy metals. When these metals accumulate in the tissues and water above the threshold and finally consumed by man through food chain, the could cause potential consequences to man. For the effective assessment of water quality, it is important to identify the potential health effects of pollutants in mine waste, stream and hand dug wells in and around the lead mining area. However, information is limited about health risks posed by potentially toxic metals in mine waters, stream water and well water in Nasarawa Eggon lead mining area. Therefore, there is the need to investigate heavy metals contamination and health risk assessment in mine water, streams and hand dug wells for worker and residents in the vicinity of the mining area.

\section{Material and Methods}

\subsection{Study Area and Site Description}

The study was carried out in Nasarawa -Eggon $\left(8^{\circ} 43^{\prime} \mathrm{N}\right.$ and $\left.8^{\circ} 32^{\prime} \mathrm{E}\right)$ the area cover a total of $247.2 \mathrm{~km}^{2}$ with a population of 148,405 and population density of 165.8 persons per $\mathrm{km}^{2}[14,15]$. The area is located in the tropical rainy climate with seven months of rainy season (April to October) and five month of dry season (November-March). The annual rainfall is about $1000-1500 \mathrm{~mm}$, while annual temperature is $22^{\circ} \mathrm{C}-25^{\circ} \mathrm{C}$. The terrain is generally hills which host most of the mines.

The $\mathrm{Pb}$ mine area is located behind Eggon Community Secondary School in Alizaga Community. The study area is prominent for local mining for the past five years and the most frequent ore mineral are galenite $(\mathrm{PbS})$ and Sphalerite $\mathrm{ZnS}$.

The tailings in the mining area remain exposed to various agents of erosion permitting a wide spatial dispersion of tailing particle. The drainage from the tailings pond runs off into streams and rivers which are used to irrigate farm land for vegetables. Communities around the mines also uses the mine tailings, waste rock and mine waste water as construction materials. Surrounding communities are therefore at potential risk from increased levels of toxic metals exposure. Figures 1 and 2 shows the map of the study area.

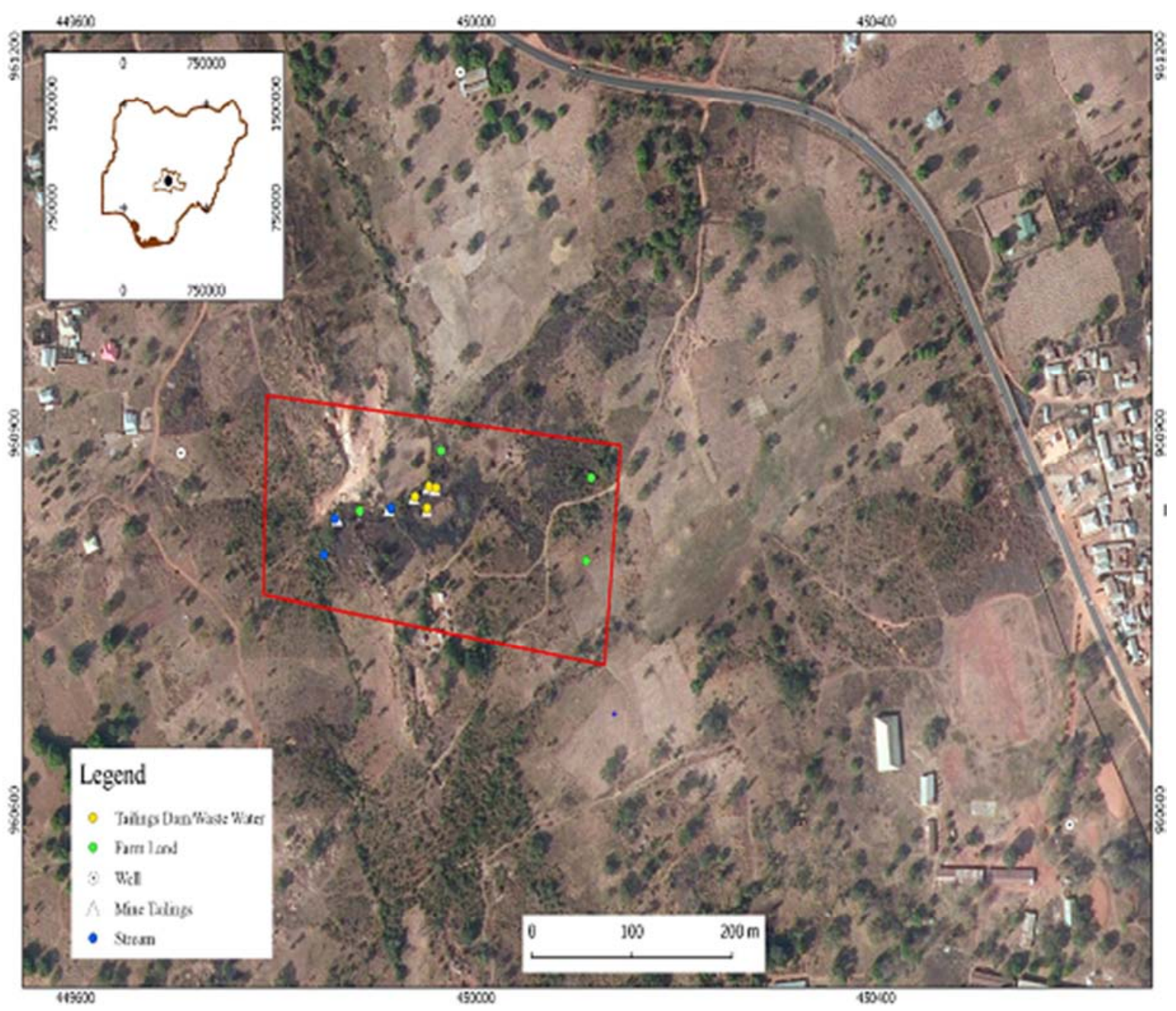

Figure 1. Map of Study Area showing the Sample Locations. 


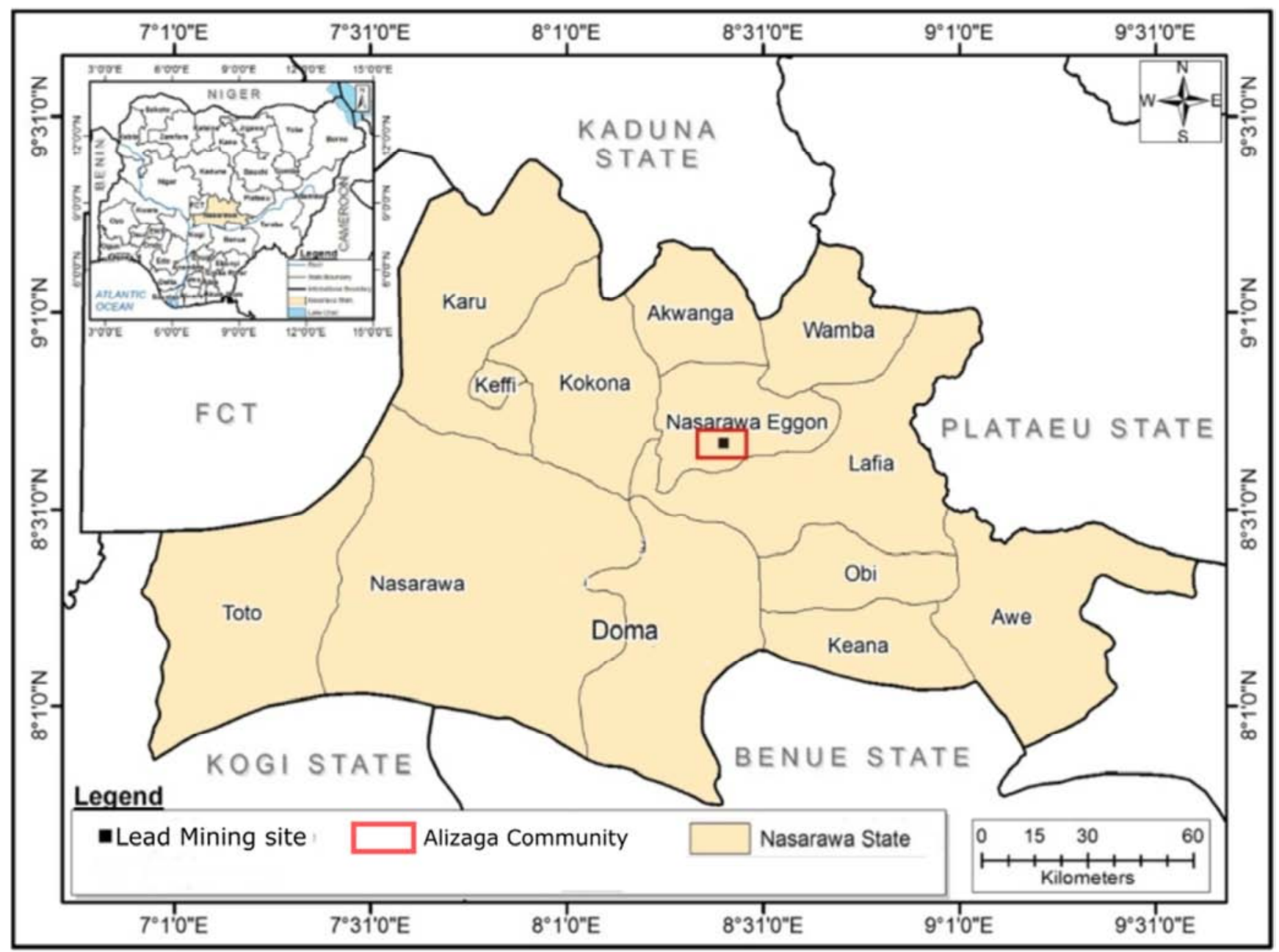

Figure 2. Map of Nasarawa State and the Study Area.

\subsection{Water Samples Collection and Preparation}

Water sampling was carried out and samples were collected from different Sampling Point in the month of March, 2019. Two hands dug well water sample, two streams water samples were collected in resident household around the mine site, these sources are representative of the drinking water sources of the inhabitants of the community. And six (6) wastewater samples were collected within the mining area, one (1) ground water sample and one (1) stream water sample were collected $3 \mathrm{~km}$ away from the study site as a control samples. A total of 12 water samples were collected and close attention was paid to every sample to avoid cross contamination. All water samples were collected in a clean labelled polyethylene bottles and were acidified with $\mathrm{HNO}_{3}$ $(1 \mathrm{~mL} / \mathrm{L}$ of water sample) in order to keep the $\mathrm{pH}$ of the sample low, subsequently preventing precipitation of the metal and store at $4^{\circ} \mathrm{C}$ before analysis [16].

\subsection{Digestion of Water Sample}

To ensure the removal of organic impurities from the samples and thus prevent interference in analysis, the samples were digested with concentrated nitric acid. Fifty (50) $\mathrm{mL}$ of the water sample was measured and $10 \mathrm{~mL}$ of nitric acid was added to the water sample in a $250 \mathrm{~mL}$ conical flask. The mixture was evaporated to half its volume on hot plate after which it was allowed to cool and then filtered with Whatman No. 42 filter paper. The filtrate was diluted to $50 \mathrm{~mL}$ with de-ionized distilled water. A blank solution was prepared according to standard method [17].

\subsection{Quality Assurance and Quality Control}

Strict quality assurance and quality control are important to ensure the authenticity, correctness and precision of the results. All the reagents and chemicals used were of analytical grade glass wares used during laboratory analysis were thoroughly washed with several changes of $9 \% \mathrm{HNO}_{3}$ and properly rinsed several times using deionized water. Dilutions were carried out using de-ionized water. A blank solution and standards were analysed along with the replicate samples to ensure precision and accuracy of the determinations.

\subsection{Heavy Metal Determination}

The digested water samples were analyzed for the presence of eight heavy metals namely $\mathrm{Hg}, \mathrm{As}, \mathrm{Pb}, \mathrm{Cd}, \mathrm{Cr}, \mathrm{Zn}, \mathrm{Cu}$ and $\mathrm{Ni}$ using the Biotech engineering management $\mathrm{Co}$; Ltd (UK) 
FAAS Phoenix 986 Atomic adsorption spectrophotometer, at the Soil Science Laboratory, ABU Zaria, Kaduna. The calibration curves were prepared by running different concentration of the standard solution and were used as a standard for sample measurement. The instrument was set to zero by running the respective reagent blanks to check for contamination and drift. The detection limits for $\mathrm{As}, \mathrm{Pb}, \mathrm{Cu}$, $\mathrm{Cr}, \mathrm{Cd}, \mathrm{Ni}, \mathrm{Zn}$ and $\mathrm{Hg}$ were $0.001,0.01,0.001,0.004,0.003$, $0.09,0.005$ and 0.001 respectively. The digested water analyzed, the concentration of the metals presents being displayed in $\mathrm{mg} / \mathrm{L}$ by the instrument.

\subsection{Statistical Analysis}

Statistical analysis involved determination of mean, medium, standard deviation, minimum, maximum, significant differences, and ANOVA. In order to meet the principles of the analysis of variance (additivity, homogeneity of variance and normality of distribution), the data were subjected to logarithmic transformation prior to the analysis.

\section{Results and Discussion}

\subsection{Concentration of Toxic Heavy Metals in Water Sample}

The presence of heavy metals in water higher than a certain concentration can cause detrimental impacts on human health. Therefore, the analysis of heavy metals in water is important. In this present study of mine wastewater, stream water and well water from and around the mine area, the results of eight priorities toxic metal (As, $\mathrm{Cd}, \mathrm{Cu}, \mathrm{Hg}, \mathrm{Ni}$, $\mathrm{Pb}$ and $\mathrm{Zn}$ with their standard limits set by WHO and NESREA [18, 19] are shown in Table 1 and Figures 3-8. There is significant difference in individual element among the sample locations and each location showed similar trends of elements ( $p<0.05$ ANOVA) except for $\mathrm{Cd}$. Their concentration sequence is $\mathrm{Pb}>\mathrm{Zn}>\mathrm{Cu}>\mathrm{Cd}>\mathrm{Cr}>\mathrm{Ni}>$ $\mathrm{Hg}>$ As.

Table 1. Total Mean concentration of Heavy Metals $(\mathrm{mg} / \mathrm{L})$ in the Mine waste water (MWW), Well water (WLW) and Stream water (STW) with WHO and NESREA Standard Limit.

\begin{tabular}{|c|c|c|c|c|c|}
\hline \multirow{2}{*}{ Heavy metal mg/L } & \multirow{2}{*}{ Sample I. D } & \multicolumn{2}{|l|}{ Range } & \multicolumn{2}{|c|}{ Standard Limit } \\
\hline & & Mean \pm S. D & Min Max & WHO & NESREA \\
\hline & MWW & $0.09 \pm 0.01$ & $0.40-2.11$ & & \\
\hline \multirow[t]{3}{*}{$\mathrm{Cu}$} & WLW & $0.06 \pm 0.01$ & $0.05-0.68$ & 2.0 & 0.1 \\
\hline & STW & $0.07 \pm 0.01$ & $0.06-0.08$ & & \\
\hline & MWW & $6.60 \pm 0.02$ & $3.69-8.40$ & & \\
\hline \multirow[t]{3}{*}{$\mathrm{Zn}$} & WLW & $1.12 \pm 0.02$ & $1.05-1.22$ & 3.0 & 5.0 \\
\hline & STW & $1.31 \pm 0.02$ & $1.19-1.45$ & & \\
\hline & MWW & $0.68 \pm 0.14$ & $0.47-0.94$ & & \\
\hline \multirow[t]{3}{*}{$\mathrm{Cd}$} & WLW & $0.93 \pm 0.13$ & $0.80-1.11$ & 0.003 & 0.01 \\
\hline & STW & $0.89 \pm 0.13$ & $0.75-1.08$ & & \\
\hline & MWW & $0.26 \pm 0.003$ & $0.23-0.27$ & & \\
\hline \multirow[t]{3}{*}{$\mathrm{Cr}$} & WLW & $0.25 \pm 0.003$ & $0.24-0.25$ & 0.05 & 0.05 \\
\hline & STW & $0.25 \pm 0.003$ & $0.24-0.25$ & & \\
\hline & MWW & $0.05 \pm 0.13$ & $0.002-0.41$ & & \\
\hline \multirow[t]{6}{*}{$\mathrm{Ni}$} & WLW & $0.03 \pm 0.12$ & $0.01-0.07$ & 0.02 & 0.05 \\
\hline & STW & $0.06 \pm 0.12$ & $0.03-0.10$ & & \\
\hline & MWW & $21.45 \pm 0.34$ & $16.98-30.11$ & & \\
\hline & WLW & $0.31 \pm 0.03$ & $0.20-0.43$ & 0.01 & 0.01 \\
\hline & STW & $0.45 \pm 0.03$ & $0.24-0.64$ & & \\
\hline & MWW & $21.45 \pm 0.34$ & $16.98-30.11$ & & \\
\hline \multirow[t]{3}{*}{$\mathrm{Pb}$} & WLW & $0.31 \pm 0.03$ & $0.20-0.43$ & 0.01 & 0.01 \\
\hline & STW & $0.45 \pm 0.03$ & $0.24-0.64$ & & \\
\hline & MWW & $0.002 \pm 0.0009$ & $0.0003-0.009$ & & \\
\hline \multirow[t]{3}{*}{$\mathrm{Hg}$} & WLW & Not detected & & 0.001 & 0.001 \\
\hline & STW & Not detected & & & \\
\hline & MWW & $0.001 \pm 0.0002$ & $0.001-0.002$ & & \\
\hline \multirow[t]{2}{*}{ As } & WLW & Not detected & & 0.01 & 0.2 \\
\hline & STW & Not detected & & & \\
\hline
\end{tabular}




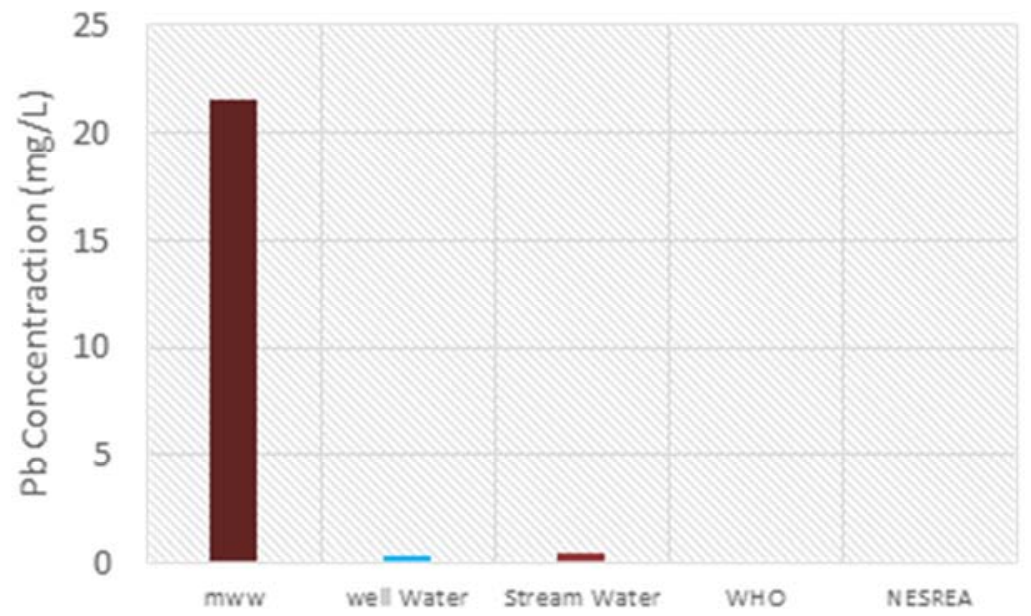

Figure 3. Pb Concentration in Water Samples from various Location with Standard Limit.

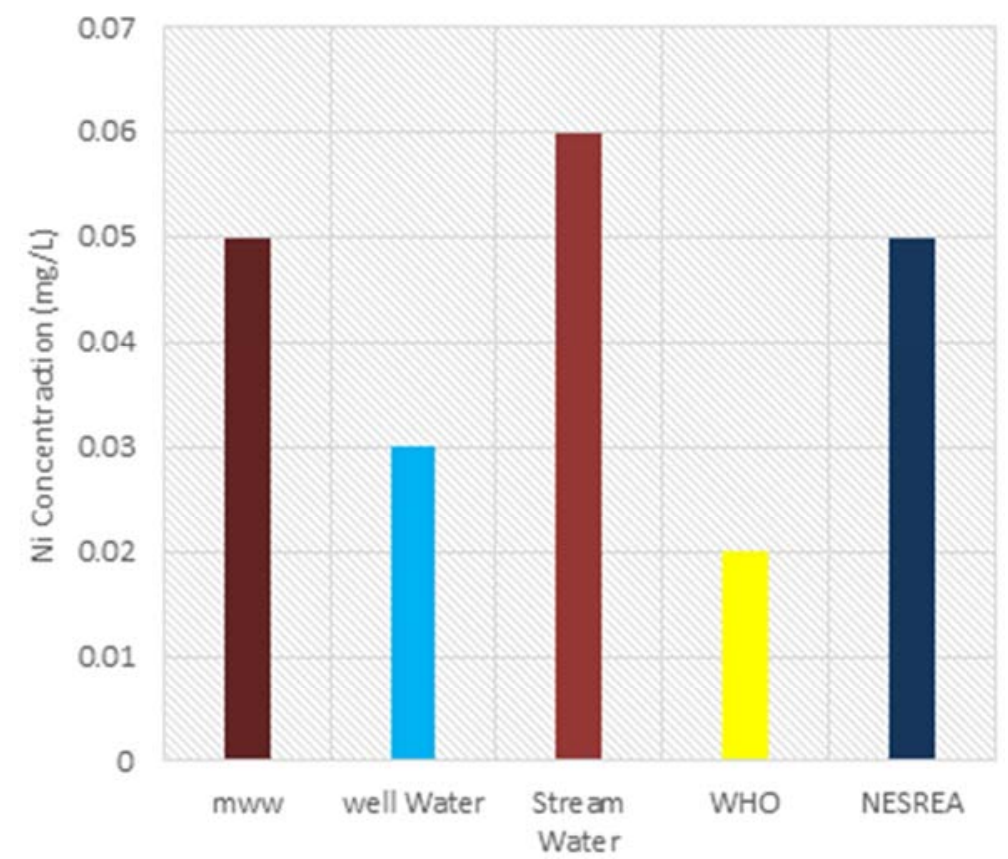

Figure 4. Ni Concentration in Water Samples from various Location with Standard Limit.

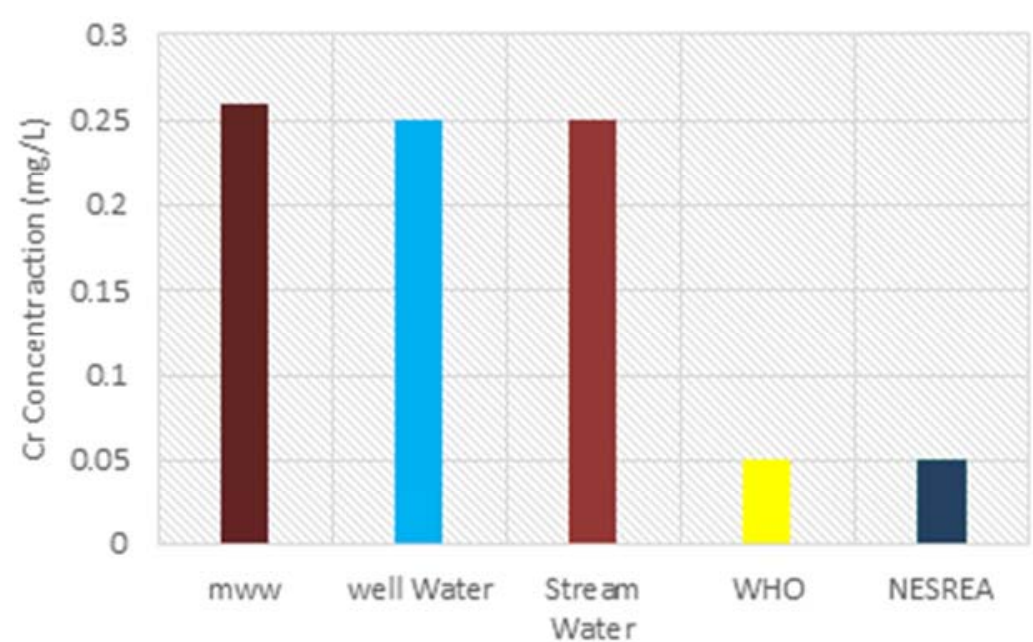

Figure 5. Cr Concentration in Water Samples from various Location with Standard Limit. 


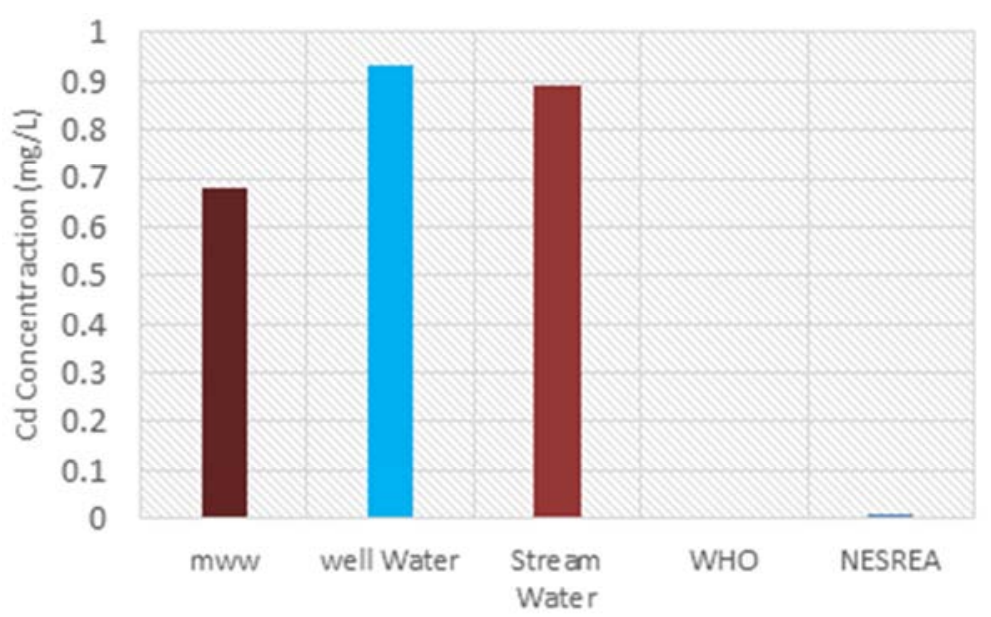

Figure 6. Cd Concentration $\mathrm{mg} / \mathrm{L}$ in Water Samples from various Location with Standard Limit.

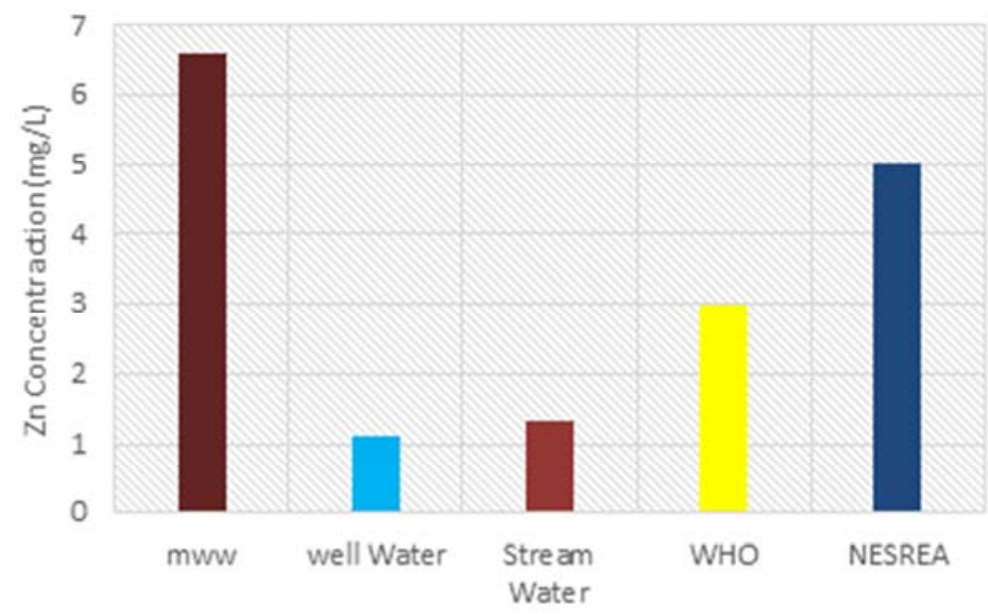

Figure 7. Zn Concentration in Water Samples from various Location with Standard Limit

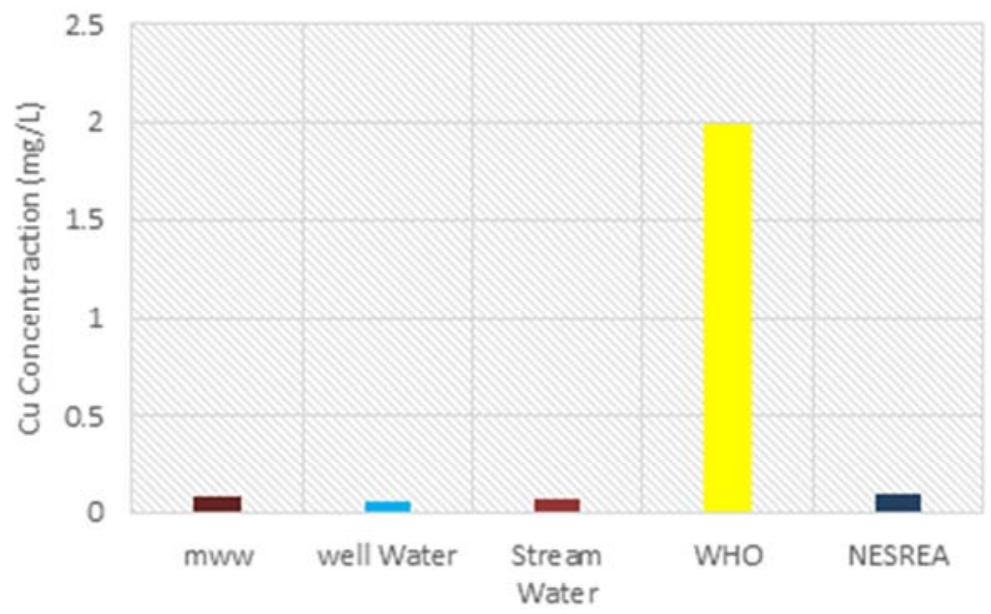

Figure 8. Cu Concentration in Water Samples from various Location with Standard Limit.

\subsubsection{Copper ( $\mathrm{Cu})$}

The mean concentration value of copper in the mine waste water (MWW), stream water and well water were $1.09 \pm 0.01$, $0.07 \pm 0.01,0.06 \pm 0.01 \mathrm{mg} / \mathrm{L}$, with ranged values of 0.40 $2.11 \mathrm{mg} / \mathrm{L}, \quad 0.06-0.08 \mathrm{mg} / \mathrm{L}$ and $0.05-0.68 \mathrm{mg} / \mathrm{L}$, respectively. Comparing the results obtained in this study, the concentration recorded for stream water agrees with
$0.06 \pm 0.04 \mathrm{mg} / \mathrm{L}$ reported by Nnabo [20], but was lower than $2.40 \pm 1.22 \mathrm{mg} / \mathrm{L}$ reported by Yaya et al., (2017). For mine waste water, the $3.19 \pm 3.35$ and $13.6 \pm 17.3 \mathrm{mg} / \mathrm{L}$ mean concentration reported by Nnabo [20] and Yaya et al. [21] were higher than the concentration obtained in this study.

The result of $\mathrm{mww}_{3}$ showed slightly higher concentration of $2.11 \mathrm{mg} / \mathrm{L}$ than WHO $(2.0 \mathrm{mg} / \mathrm{L})$ standard limit. Other 
sample locations showed concentration lower than the recommended limit set by WHO. Well water samples and stream water samples were observed to have concentrations below WHO and NESREA $(0.1 \mathrm{mg} / \mathrm{L})$ recommended limit. Across the sampling locations the concentration of $\mathrm{Cu}$ was differed significantly (ANOVA $\mathrm{P}<0.05$ ). The control site concentration for both well and stream showed $0.07 \mathrm{mg} / \mathrm{L}$ and $0.06 \mathrm{mg} / \mathrm{L}$ lower than concentration obtained from all the sample locations. Considering the guidelines set by WHO, NESREA [18, 19] and the concentration obtained from the control sample site, the well water and the stream water can be considered wholesome with respect to copper content. This also implies that the well water from surrounding environment and stream water from the mining area may be safe from $\mathrm{Cu}$ metal pollution.

\subsubsection{Zinc (Zn)}

Zinc plays an important role in protein synthesis and is a metal, which shows low concentration in surface water due to it restricted mobility from the place of rock weathering or from neutral source [22]. The concentration of zinc in mine waste water, well water and stream water were $6.60 \pm 0.02$, $1.12 \pm 0.02$ and $1.31 \mathrm{mg} / \mathrm{L}$ with ranges from 3.69-8.40, 1.051.22 and $1.19-1.45$, respectively. For mine waste water (mww) samples, the concentration obtained was higher than the WHO (3 mg/L) and NESREA ( $5 \mathrm{mg} / \mathrm{L})$ recommended limit $[18,19]$. Concentration of well water sample and stream water samples were observed to be lower than WHO and NESREA recommended standard limit. Further comparison of the results of mww, stream water and well water samples with the control sample site (well water $0.86 \mathrm{mg} / \mathrm{L}$ and stream water $0.96 \mathrm{mg} / \mathrm{L}$ ) showed that the concentration obtained from the study area were higher than concentration value reported from control site. The mean concentration of $\mathrm{Zn}$ among the three sites (waste water, stream and well) differed significantly $(\mathrm{P}<0.05)$. Zamani et al. [23] in a similar studied on assessment of heavy metal pollution sources of ground water around a lead and zinc in Iran reported $\mathrm{Zn}$ concentration higher than the concentration obtained in this study. Similarly, Nnabo [20] and Yaya et al. [21] reported a higher concentration for ground water and stream water with lower concentration of pond water from assessment of heavy metal concentration of water source from Enyigba $\mathrm{Pb}-\mathrm{Zn}$ district, south eastern, Nigeria and Guangdong China.

\subsubsection{Lead (Pb)}

Lead mean value in mine waste water, well water and stream water were $21.5 \pm 0.034,0.31 \pm 0.03$ and $0.45 \pm 0.03$ $\mathrm{mg} / \mathrm{L}$ with ranged concentration of $16.98-30.41,0.20-0.43$ and $0.24-0.64 \mathrm{mg} / \mathrm{L}$. in the entire sites, the concentration recorded were higher than the $0.01 \mathrm{mg} / \mathrm{L}$ recommended value set by WHO and NESREA. The result of mww obtained from this studied was 70 times higher than the concentration in stream and well water. The concentration of waste water was 210 times higher than WHO limit for water quality.

The $\mathrm{Pb}$ concentration of $0.45 \mathrm{mg} / \mathrm{L}$ in well water was 45 times higher than WHO recommended limit for water quality. This is expected as local $\mathrm{Pb}$ mining is very active in the area
[20]. Comparison of $\mathrm{Pb}$ concentration from this study with other similar studied, Zamani et al. [23] reported a low concentration range of $0.74-12.45 \mathrm{mg} / \mathrm{L}$ from assessment of heavy metal pollution sources of ground water around a lead and zinc plant in Iran. While Nanbo [20] also reported a low concentration of $0.1 \mathrm{mg} / \mathrm{L}$ in ground water and a high concentration of $2.3 \mathrm{mg} / \mathrm{L}$ in stream water from Enyigba $\mathrm{Pb} / \mathrm{Zn}$ district, South Eastern Nigeria. On the other hand, Yaya et al. [21] reported high $\mathrm{Pb}$ concentration of $4.33 \mathrm{mg} / \mathrm{L}$ and $7.71 \mathrm{mg} / \mathrm{L}$ in surface and ground water in the vicinity of a tailing pond in Guangdong China. Lead contaminations of water bodies (stream, well borehole and river) and environment lead to death of several people and animals. Lead poisoning is one of the most common and bestrecognized childhood diseases of toxic environmental origin [13]. Children around the world today are at risk of exposure to lead from multiple sources lead poisoning accounts for about $0.6 \%$ of the global burden of diseases [24]. More recent cases of lead poisoning have been reported in Zamfara and Niger State, Nigeria [25].

\subsubsection{Cadmium (Cd)}

Cadmium mean concentration in mining waste water, well water and stream water samples were found to be $0.68 \pm 0.14$, $0.93 \pm 13$ and $0.89 \pm 8.00 \mathrm{mg} / \mathrm{L}$ with concentration ranged of $0.47-0.94 \mathrm{mg} / \mathrm{L}, \quad 0.80-1.11 \mathrm{mg} / \mathrm{L}$ and $0.75-1.08 \mathrm{mg} / \mathrm{L}$ respectively. Cadmium concentration from all the samples locations were observed to be higher than the $0.003 \mathrm{mg} / \mathrm{L}$ and $0.01 \mathrm{mg} / \mathrm{L}$ concentration recommended by $\mathrm{WHO}$ and NESREA guidelines. Cadmium results from this study when compared with the result reported by Mohammad et al. [5] on determination of some heavy metal in waste water and sediment in Abare, North Western Nigeria. The waste water concentration was extremely lower $(0.004 \mathrm{mg} / \mathrm{L})$ than the concentration of waste water obtained in this study. Similarly, Nnabo [20] reported cadmium value of $0.05 \mathrm{mg} / \mathrm{L}$ for ground water and values of $13.5,12.3$ and $6.0 \mathrm{mg} / \mathrm{L}$ for stream water from assessment of heavy metal concentration of water sources from Enyigba $\mathrm{Pb} / \mathrm{Zn}$ district, South Eastern Nigeria. These reported value for ground water was lower than 0.93 $\mathrm{mg} / \mathrm{L}$ concentration obtained from well water in this study, those for stream water were higher than $0.89 \mathrm{mg} / \mathrm{L}$ concentration obtained from stream water in this study. The mean concentration of cadmium in the mine waste water, stream water and well water varied significantly $(\mathrm{P}<0.05)$ among the sampling locations.

\subsubsection{Chromium}

Chromium has a concentration ranged value of $0.26-0.003$ $\mathrm{mg} / \mathrm{L}$ in mining waste water in well water, the mean concentration was $0.25 \pm 0.003 \mathrm{mg} / \mathrm{L}$ with ranged concentration of $0.24-0.25 \mathrm{mg} / \mathrm{L}$. when compared with WHO and NESREA recommended standard limit for water quality i.e. $0.05 \mathrm{mg} / \mathrm{L}$, the concentration value obtained from mining waste water, stream water and well water were higher than recommended limit. Further comparison of the result of this study with other similar studied, Yaya et al., [21] reported higher $\mathrm{Cr}$ concentration $(1.69 \pm 1.10$ and $3.69 \pm 3.73) \mathrm{mg} / \mathrm{L}$ in surface water and ground water in the vicinity of a tailing 
pond in Guangdong China. Similarly Muhammad et al., [5] reported a lower $\mathrm{Cr}$ concentration of $0.0001 \pm 0.0008 \mathrm{mg} / \mathrm{L}$ in mine waste water of Abare area of Zamfara State, Nigeria. Chromium mean concentration do not different significantly $(\mathrm{P}>0.05)$ among the samples locations of the three sites.

\subsubsection{Nickel (Ni)}

Nickel has a mean concentration of $0.05 \pm 0.13 \mathrm{mg} / \mathrm{L}$ with ranged concentration of $0.002-0.41 \mathrm{mg} / \mathrm{L}$ in mining waste water sample, mean concentration of $0.03 \pm 0.02 \mathrm{mg} / \mathrm{L}$ with ranged concentration of $0.01-0.07 \mathrm{mg} / \mathrm{L}$ in the well water and a mean concentration of $0.06 \pm 0.12 \mathrm{mg} / \mathrm{L}$ with ranged concentration of $0.03-0.10 \mathrm{mg} / \mathrm{L}$ in the stream water sample. When compared with WHO $(0.02 \mathrm{mg} / \mathrm{L})$ and NESREA $(0.05$ $\mathrm{mg} / \mathrm{L}$ ) standard limit for water quality, the value obtained for mining waste water was within the standard limit set by NESREA but higher than the limit set by WHO, well water concentration of $0.03 \mathrm{mg} / \mathrm{L}$ was lower than NESREA standard limit but high than the $0.02 \mathrm{mg} / \mathrm{L}$ standard limit set by WHO similarly, $0.06 \mathrm{mg} / \mathrm{L} \mathrm{Ni}$ concentration in stream water sample was higher than both NESREA and WHO recommended limit for water quality. The value obtained in this study was lower than the $84.15 \mathrm{mg} / \mathrm{L}$ reported by Zamani et al. [23] in ground water around a lead-zinc plant in Iran. While Nnabo [20] also reported higher concentration of 0.31 and $9.95 \mathrm{mg} / \mathrm{L}$ for ground water and stream water from Enyigba $\mathrm{Pb}-\mathrm{Zn}$ district South Eastern, Nigeria.

\subsubsection{Mercury $(\mathrm{Hg})$}

Mercury has mean concentration of $0.002 \pm 0.0009 \mathrm{mg} / \mathrm{L}$ with a ranged value of $0.0003-0.0009 \mathrm{mg} / \mathrm{L}$ in waste water sample. Mercury was not detected in stream water and well water samples. But when compared with WHO/NESREA guidelines for water quality the value obtained for waste water was high than the $0.001 \mathrm{mg} / \mathrm{L}$ acceptable limit for $\mathrm{Hg}$ in drinking water. The $\mathrm{Hg}$ is lower and value extremely lower than the 0.02 and $7.28 \mathrm{mg} / \mathrm{L}$ reported by Adamu et al. [26] and Muhammad et al. [5] in similar studied in Cross River State and Zamfara State, Nigeria.

\subsubsection{Arsenic (As)}

Arsenic was not detected in both stream and well water sample of the study area. Arsenic was found in mining waste water. It has a mean concentration of $0.001 \pm 0.0002 \mathrm{mg} / \mathrm{L}$ with a ranged concentration between $0.001-0.002 \mathrm{mg} / \mathrm{L}$. when compared with WHO $(0.01 \mathrm{mg} / \mathrm{L})$ and NESREA $(0.02$ $\mathrm{mg} / \mathrm{L}$ ) recommended limit for portable water. The value of Arsenic obtained was extremely lower than $2.2 \mathrm{mg} / \mathrm{L}$ concentration reported by Nnabo [20] in mine ponds water from Enyigba $\mathrm{Pb}-\mathrm{Zn}$ district South Eastern Nigeria. On the other hand, Arsenic concentration recorded in this study agrees with concentration reported by Adamu et al. [26] from a similar studied conducted in Cross River State, Southeastern Nigeria.

\subsection{Correlation Analysis of Heavy Metal in Water}

A correlation analysis was used to establish the relationships, as well as evaluating their common source of the detected heavy metals in the well water and mining wastewater (mww). The Pearson correlation results are presented in the table below.

Table 2. Correlation coefficients between the measured parameter of $m w w$ and well water.

\begin{tabular}{|c|c|c|c|c|c|c|c|c|c|}
\hline & $\mathbf{C u}$ & $\mathbf{Z n}$ & Cd & $\mathrm{Cr}$ & $\mathbf{N i}$ & $\mathbf{P b}$ & Hg & As & Sites \\
\hline $\mathrm{Cu}$ & 1 & & & & & & & & \\
\hline $\mathrm{Zn}$ & $.928 * *$ & 1 & & & & & & & \\
\hline $\mathrm{Cd}$ & $-.0835 * *$ & $-.0835 * *$ & 1 & & & & & & \\
\hline $\mathrm{Cr}$ & .019 & -.005 & .028 & 1 & & & & & \\
\hline $\mathrm{Ni}$ & .072 & .118 & -.071 & -.205 & 1 & & & & \\
\hline $\mathrm{Hg}$ & $.367 *$ & $.334 *$ & $-.498 * *$ & .0 .64 & .146 & $.517 * *$ & 1 & & \\
\hline As & $.800 * *$ & $.925^{* *}$ & $-.604 * *$ & .008 & .087 & $.962 * *$ & $.388^{*}$ & 1 & \\
\hline Sites & $-.698 * *$ & $-.822 * *$ & $.634 * *$ & .058 & -.088 & $-.835 * *$ & $-.590 * *$ & $-.843 * *$ & 1 \\
\hline
\end{tabular}

** Correlation is significant at the 0.01 level (2-tailed)

* Correlation is significant at the 0.05 level (2-taileed)

A correlation analysis was used to establish the relationships, as well as evaluating their common source of the detected heavy metals in the well water and wastewater (mww). The Pearson correlation results are presented in Table 2 .

The Pearson correlation analysis revealed that $\mathrm{Cu}$ had a strong positive correlation with $\mathrm{Zn}, \mathrm{Pb}$ and $\mathrm{As}$ ( $\mathrm{r}=0.928$, $0.782,0.800, \mathrm{p}<0.01)$ and negatively correlation with $\mathrm{Cd}$ and the samples sites $(\mathrm{r}=-0.618, \mathrm{P}<0.01)$. it was also observed that a weak correlation exists between $\mathrm{Cu}, \mathrm{Cr}$ and $\mathrm{Ni}(\mathrm{r}=0.019,0.072)$.

$\mathrm{Zn}$ had strong positive correlation with $\mathrm{Pb}, \mathrm{As}$ and $\mathrm{Hg}$ $(\mathrm{r}=0.877,0.925, \mathrm{P}<0.01$ and $0.334, \mathrm{P}<0.005)$. The metal was also negatively correlated with $\mathrm{Cd}$ and the samples sites $(\mathrm{r}=0.640$ and $0.822, \mathrm{P}<0.01)$. $\mathrm{Cd}$ also had a strong positive correlation with the sample site $(\mathrm{r}=0.634, \mathrm{P}<0.01)$ but a weak correlation (0.008) was observed between $\mathrm{Cd}$ and $\mathrm{Cr}$. The correlation analysis of heavy metal concentration from the samples site (mww and well water) showed $\mathrm{Pb}$ strong positive correlated with $\mathrm{As}$ and $\mathrm{Hg}$ but negative correlated with the sample sites. $(\mathrm{r}=0.517,0.962,0.835 \mathrm{P}<0.01)$. the results also revealed negative correlation between $\mathrm{Hg}$, As and the sample sites. The positive correlation of the heavy metals 
suggests that $\mathrm{Pb}, \mathrm{Zn}, \mathrm{As}, \mathrm{Cu}$ and $\mathrm{Hg}$ are derived from the same source and the presence of the one can affect the other. The negative correlation detected $\mathrm{Cu} / \mathrm{Cd}, \mathrm{Zn} / \mathrm{Cd}$, $\mathrm{Cu} /$ site, $\mathrm{Pb} /$ sites and $\mathrm{As} /$ sites suggests that the heavy metals and the site (mww and well water) are influence) by different anthropogenic activities. Poor or weak correlation could be attributed to differences in mixed sources of origin and behavior of those heavy metals as well as an anthropogenic influence [27].

\subsection{Human Health Risk Assessment of the Mine Waste Water (wmm), Stream Water (SLW) and Well Water $(\boldsymbol{W L} \boldsymbol{W})$}

The human health risk assessment was evaluated using the USEPA risk assessment method [28]. Tables 3-6 shows results of Average Daily Dose $\left(\mathrm{ADD}_{\text {ing }}, \mathrm{ADD}_{\text {derm }}\right)$, Hazard Quotient ( $\left.\mathrm{HQ}_{\text {ing, }} \mathrm{HQ}_{\text {derm }}\right)$, Hazard Index (HI), CDI and Cancer Risk (CR) for the eight heavy metals in the samples sites.

Table 3. Health Risk Assessment for Metals in Mining Waste Water.

\begin{tabular}{|c|c|c|c|c|c|c|c|c|c|c|}
\hline \multirow{2}{*}{$\begin{array}{l}\text { Water } \\
\text { Sample }\end{array}$} & \multirow{2}{*}{$\begin{array}{l}\text { Exposure } \\
\text { Parameter }\end{array}$} & \multicolumn{8}{|c|}{ Health Risk Assessment } & \multirow{2}{*}{$\begin{array}{l}\text { Hazard } \\
\text { Index }\left(\sum H I\right)\end{array}$} \\
\hline & & $\mathbf{C u}$ & Zn & Cd & $\mathrm{Cr}$ & $\mathbf{N i}$ & $\mathbf{P b}$ & $\mathrm{Hg}$ & As & \\
\hline \multirow{8}{*}{ Mww } & ADDing & $3.1 \times 10^{-2}$ & $0.19 \times 10^{0}$ & $0.02 \times 10^{0}$ & $7.4 \times 10^{-3}$ & $4.3 \times 10^{-3}$ & $0.61 \times 10^{0}$ & $5.7 \times 10^{-3}$ & $2.9 \times 10^{-5}$ & \\
\hline & ADDderm & $2.6 \times 10^{-4}$ & $9.3 \times 10^{-5}$ & $1.6 \times 10^{-4}$ & $6.2 \times 10^{-5}$ & $4.8 \times 10^{-5}$ & $5.2 \times 10^{-4}$ & $4.8 \times 10^{-4}$ & $2.4 \times 10^{-7}$ & \\
\hline & HQing & $0.78 \times 10^{0}$ & $0.63 \times 10^{0}$ & $40.0 \times 10^{0}$ & $2.47 \times 10^{0}$ & $0.20 \times 10^{0}$ & $17.4 \times 10^{0}$ & $0.19 \times 10^{0}$ & $0.10 \times 10^{0}$ & 218.7 \\
\hline & HQderm & $0.11 \times 10^{0}$ & $1.27 \times 10^{0}$ & $0.32 \times 10^{0}$ & $1.00 \times 10^{0}$ & $8.57 \times 10^{-3}$ & $1.00 \times 10^{0}$ & $16.0 \times 10^{0}$ & $2.67 \times 10^{-5}$ & 18.4 \\
\hline & $\sum H Q$ & $0.89 \times 10^{0}$ & $0.63 \times 10^{0}$ & $40.3 \times 10^{0}$ & $3.47 \times 10^{0}$ & $0.21 \times 10^{0}$ & $17.5 \times 10^{0}$ & $16.2 \times 10^{0}$ & $0.100 \times 10^{0}$ & 236.8 \\
\hline & CDI & $0.031 \times 10^{0}$ & $0.19 \times 10^{0}$ & $1.90 \times 10^{-2}$ & $7.40 \times 10^{-3}$ & $1.40 \times 10^{-3}$ & $0.61 \times 10^{0}$ & $5.70 \times 10^{-3}$ & $2.90 \times 10^{-5}$ & \\
\hline & CRing & $7.60 \times 10^{-3}$ & $3.70 \times 10^{-3}$ & $3.61 \times 10^{-3}$ & $5.17 \times 10^{-3}$ & $4.35 \times 10^{-5}$ & & & & \\
\hline & CRdermal & $2.61 \times 10^{-8}$ & $1.24 \times 10^{-7}$ & $2.26 \times 10^{-4}$ & $6.12 \times 10^{-5}$ & $1.60 \times 10^{-7}$ & & & & \\
\hline
\end{tabular}

Table 4. Health Risk Assessment for Metals in Stream Water.

\begin{tabular}{|c|c|c|c|c|c|c|c|c|}
\hline \multirow{2}{*}{ Water sample } & \multirow{2}{*}{$\begin{array}{l}\text { Exposure pathways / } \\
\text { parameter }\end{array}$} & \multicolumn{7}{|c|}{ Health Risk Assessment for Metals in Stream Water 1} \\
\hline & & $\mathbf{C u}$ & $\mathbf{Z n}$ & Cd & $\mathbf{C r}$ & $\mathbf{N i}$ & $\mathbf{P b}$ & $\left(\sum \mathbf{H I}\right)$ \\
\hline \multirow{7}{*}{ Stream Water 1} & ADDing & $1.86 \times 10^{-3}$ & $3.43 \times 10^{-2}$ & $2.42 \times 10^{-2}$ & $7.14 \times 10^{-3}$ & $2.4 \times 10^{-3}$ & $1.76 \times 10^{-5}$ & \\
\hline & ADDderm & $1.56 \times 10^{-3}$ & $1.53 \times 10^{-3}$ & $2.04 \times 10^{-4}$ & $6.02 \times 10^{-5}$ & $8.06 \times 10^{-5}$ & $1.47 \times 10^{-5}$ & \\
\hline & HQing & $4.65 \times 10^{-2}$ & $1.20 \times 10^{-1}$ & $4.84 \times 10^{0}$ & $2.38 \times 10^{0}$ & $1.20 \times 10^{-1}$ & $5.03 \times 10^{0}$ & 12.54 \\
\hline & HQderm & $6.50 \times 10^{-1}$ & $2.00 \times 10^{-3}$ & $4.10 \times 10^{-1}$ & $1.00 \times 10^{0}$ & $1.40 \times 10^{-2}$ & $2.80 \times 10^{0}$ & 2.12 \\
\hline & $\sum \mathrm{HQ}$ & $7.00 \times 10^{-1}$ & $1.40 \times 10^{-1}$ & $5.25 \times 10^{0}$ & $3.38 \times 10^{0}$ & $1.30 \times 10^{-1}$ & $5.06 \times 10^{0}$ & 23.39 \\
\hline & CDI & $1.89 \times 10^{-3}$ & $3.40 \times 10^{-2}$ & $2.50 \times 10^{-2}$ & $7.27 \times 10^{-3}$ & $2.41 \times 10^{-3}$ & $1.79 \times 10^{-2}$ & \\
\hline & CRing & $9.12 \times 10^{-3}$ & $3.57 \times 10^{-3}$ & $2.02 \times 10^{-3}$ & $1.50 \times 10^{-4}$ & & & \\
\hline \multirow{9}{*}{ Stream Water 2} & CRdermal & $7.75 \times 10^{-5}$ & $3.01 \times 10^{-5}$ & $6.77 \times 10^{-5}$ & $1.25 \times 10^{-7}$ & & & \\
\hline & ADDing & $1.97 \times 10^{-3}$ & $4.09 \times 10^{-2}$ & $2.47 \times 10^{-2}$ & $7.09 \times 10^{-3}$ & $1.06 \times 10^{-3}$ & $7.57 \times 10^{-3}$ & \\
\hline & ADDderm & $1.66 \times 10^{-5}$ & $2.06 \times 10^{-4}$ & $2.24 \times 10^{-4}$ & $8.06 \times 10^{-5}$ & $3.55 \times 10^{-5}$ & $6.36 \times 10^{-6}$ & \\
\hline & HQing & $4.93 \times 10^{-2}$ & $1.40 \times 10^{-1}$ & $5.34 \times 10^{0}$ & $2.36 \times 10^{0}$ & $5.30 \times 10^{-2}$ & $5.03 \times 10^{0}$ & 10.11 \\
\hline & HQderm & $2.21 \times 10^{-4}$ & $2.75 \times 10^{-3}$ & $4.50 \times 10^{-1}$ & $1.34 \times 10^{0}$ & $6.34 \times 10^{-3}$ & $1.22 \times 10^{-2}$ & 1.81 \\
\hline & $\sum H Q$ & $4.95 \times 10^{-2}$ & $1.14 \times 10^{0}$ & $5.795 \times 10^{0}$ & $3.70 \times 10^{0}$ & $5.90 \times 10^{-2}$ & $2.17 \times 10^{0}$ & 12.91 \\
\hline & $\mathrm{CDI}$ & $2.00 \times 10^{-3}$ & $4.15 \times 10^{-2}$ & $2.71 \times 10^{-2}$ & $7.19 \times 10^{-3}$ & $1.07 \times 10^{-3}$ & $7.69 \times 10^{-3}$ & \\
\hline & CRing & $1.00 \times 10^{-2}$ & $3.55 \times 10^{-3}$ & $8.90 \times 10^{-4}$ & $6.44 \times 10^{-5}$ & & & \\
\hline & CRdermal & $8.51 \times 10^{-5}$ & $4.03 \times 10^{-5}$ & $2.98 \times 10^{-5}$ & $5.41 \times 10^{-8}$ & & & \\
\hline
\end{tabular}

Table 5. Health Risk Assessment for Metals in Well Water through Ingestion and Dermal Absorption Pathway.

\begin{tabular}{|c|c|c|c|c|c|c|c|c|}
\hline \multirow{2}{*}{$\begin{array}{l}\text { Water } \\
\text { sample }\end{array}$} & \multirow{2}{*}{$\begin{array}{l}\text { Exposure pathways / } \\
\text { parameter }\end{array}$} & \multicolumn{7}{|c|}{ Health Risk Assessment for Metals in Well Water 1} \\
\hline & & $\mathbf{C u}$ & Zn & Cd & $\mathbf{C r}$ & $\mathrm{Ni}$ & $\mathbf{P b}$ & $\left(\sum \mathbf{H I}\right)$ \\
\hline \multirow{7}{*}{ Well Water 1} & ADDing & $1.49 \times 10^{-3}$ & $3.30 \times 10^{-2}$ & $2.80 \times 10^{-2}$ & $7.14 \times 10^{-3}$ & $1.60 \times 10^{-3}$ & $6.34 \times 10^{-3}$ & \\
\hline & ADDderm & $1.25 \times 10^{-5}$ & $1.67 \times 10^{-4}$ & $2.32 \times 10^{-4}$ & $6.02 \times 10^{-5}$ & $5.38 \times 10^{-5}$ & $5.33 \times 10^{-5}$ & \\
\hline & HQing & $3.70 \times 10^{-2}$ & $1.10 \times 10^{-1}$ & $5.52 \times 10^{0}$ & $2.38 \times 10^{0}$ & $8.00 \times 10^{-1}$ & $5.03 \times 10^{0}$ & 9.94 \\
\hline & HQderm & $6.50 \times 10^{-1}$ & $2.00 \times 10^{-3}$ & $4.10 \times 10^{-1}$ & $1.00 \times 10^{0}$ & $1.40 \times 10^{-2}$ & $1.81 \times 10^{0}$ & 1.58 \\
\hline & $\sum \mathrm{HQ}$ & $4.20 \times 10^{-2}$ & $1.10 \times 10^{-1}$ & $5.56 \times 10^{0}$ & $3.40 \times 10^{0}$ & $9.00 \times 10^{-2}$ & $1.91 \times 10^{0}$ & 11.1 \\
\hline & CDI & $1.49 \times 10^{-3}$ & $3.40 \times 10^{-2}$ & $2.80 \times 10^{-2}$ & $7.25 \times 10^{-3}$ & $1.62 \times 10^{-3}$ & $6.44 \times 10^{-3}$ & \\
\hline & CRing & $1.06 \times 10^{-2}$ & $3.57 \times 10^{-3}$ & $1.38 \times 10^{-3}$ & $5.39 \times 10^{-5}$ & & & \\
\hline \multirow{9}{*}{ Well Water 2} & CRdermal & $3.80 \times 10^{-7}$ & $1.20 \times 10^{-7}$ & $6.41 \times 10^{-5}$ & $6.27 \times 10^{-9}$ & & & \\
\hline & ADDing & $1.66 \times 10^{-3}$ & $3.00 \times 10^{-2}$ & $2.60 \times 10^{-2}$ & $7.11 \times 10^{-3}$ & $2.86 \times 10^{-3}$ & $1.27 \times 10^{-1}$ & \\
\hline & ADDderm & $1.39 \times 10^{-5}$ & $1.53 \times 10^{-4}$ & $2.15 \times 10^{-4}$ & $5.98 \times 10^{-5}$ & $9.60 \times 10^{-6}$ & $9.65 \times 10^{-6}$ & \\
\hline & HQing & $4.20 \times 10^{-2}$ & $1.00 \times 10^{-1}$ & $5.20 \times 10^{0}$ & $2.37 \times 10^{0}$ & $1.40 \times 10^{-2}$ & $3.63 \times 10^{1}$ & 44.02 \\
\hline & HQderm & $3.48 \times 10^{-4}$ & $5.10 \times 10^{-4}$ & $4.30 \times 10^{-1}$ & $2.00 \times 10^{-2}$ & $2.74 \times 10^{-3}$ & $2.75 \times 10^{-4}$ & 0.45 \\
\hline & $\sum \mathrm{HQ}$ & $4.20 \times 10^{-2}$ & $1.10 \times 10^{0}$ & $5.24 \times 10^{0}$ & $2.39 \times 10^{0}$ & $1.70 \times 10^{-3}$ & $3.63 \times 10^{1}$ & 45.07 \\
\hline & $\overline{\mathrm{CDI}}$ & $1.66 \times 10^{-3}$ & $3.10 \times 10^{-2}$ & $2.60 \times 10^{-3}$ & $7.20 \times 10^{-3}$ & $2.90 \times 10^{-4}$ & $1.20 \times 10^{-2}$ & \\
\hline & CRing & $1.10 \times 10^{-2}$ & $3.60 \times 10^{-3}$ & $2.40 \times 10^{-4}$ & $1.08 \times 10^{-3}$ & & & \\
\hline & CRdermal & $8.17 \times 10^{-5}$ & $2.99 \times 10^{-5}$ & $8.06 \times 10^{-6}$ & $8.20 \times 10^{-8}$ & & & \\
\hline
\end{tabular}


Table 6. Incremental Lifetime Cancer Risk (ILCR) Value of Carcinogenic Human Health Risk through Ingestion and Dermal Contact to the Stream and Well Water of the Study Area.

\begin{tabular}{llll}
\hline \multirow{2}{*}{ Metal } & \multicolumn{3}{l}{ Incremental Lifetime Cancer Risk (ILCR) } \\
\cline { 2 - 4 } & Mean & Min & Max \\
\hline $\mathrm{Cd}$ & $5.17 \times 10^{-3}$ & $4.60 \times 10^{-3}$ & $5.54 \times 10^{-3}$ \\
$\mathrm{Cr}$ & $1.80 \times 10^{-3}$ & $1.80 \times 10^{-3}$ & $1.82 \times 10^{-3}$ \\
$\mathrm{Ni}$ & $5.90 \times 10^{-4}$ & $1.24 \times 10^{-4}$ & $1.04 \times 10^{-3}$ \\
$\mathrm{~Pb}$ & $1.69 \times 10^{-4}$ & $2.70 \times 10^{-5}$ & $5.40 \times 10^{-4}$ \\
$\mathrm{IILCR}$ & $7.74 \times 10^{-3}$ & $6.60 \times 10^{-3}$ & $8.90 \times 10^{-3}$ \\
\hline
\end{tabular}

\subsubsection{Non-Carcinogenic Analysis}

The heavy metal contamination in water distribution network can increase human health risk through various exposure route or pathways. Human health assessment of heavy metals in the present study shows that ADD through ingestion and dermal contact for mine waste water, well water and streams water were lower and below unity $(<1)$. According to USEPA risk assessment guidelines, when the value of the hazard quotient is greater than $1(>1)$, the probability of adverse health effects due to exposure is high and when the value of the hazard quotient is less than 1.0 no adverse health effect [28]. In the present study, the Hazard quotient via ingestion values for $\mathrm{Cd}, \mathrm{Cr}$ and $\mathrm{Pb}$ in all sample sites were all greater than $1(>1)$, suggesting adverse health effect. The risk assessment in this study suggested that $\mathrm{Cd}$, $\mathrm{Pb}$ and $\mathrm{Cr}$ causes more pollution due to high HQing values, exposure to high levels of the contaminant may be at high risk of illnesses in all the samples site. Similarly, HQing values for $\mathrm{Cu}, \mathrm{Zn}, \mathrm{Ni}$ and $\mathrm{As}$ in all the samples sites were observed to be $<1$, and this suggested no adverse health effect or an acceptable level of non-carcinogenic adverse health risk. Values of HQderm contact for $\mathrm{Cu}, \mathrm{Zn}, \mathrm{Cd}, \mathrm{Ni}, \mathrm{Pb}$ and As were observed to be $\leq 1$ in all the samples sites. Except for stream water 2 whose HQderm value for $\mathrm{Cr}$ was slightly greater than 1 . This results agrees with HQing value reported by Adamu et al. [26] in a similar studied.

The Hazard Index (HI) for ingestion for all of the heavy metals in each of the sample site were 218.66, 9.94, 44.02, 12.54 and 10.11 for mww, well water 1 , well water 2 , stream water 1 and stream water 2 respectively while the computed values for hazard index (HI) for dermal contact exposure were $18.44,1.58,0.45,2.12$ and 1.81 for mww, well water 1 , well water 2 , stream water 1 and stream water 2 , respectively. On the other hand, Hazard Index for dermal contact for wells water and streams water samples shows no or minimal cumulative potential for adverse health risk to the water user.

The Chromic Daily Intake (CDI) values for all the toxic metals from all the sampling sites showed high CDI indicating that the on-going mining activities and agricultural practices like fertilization and run-off has greatly influenced the stream water and well water of the study area. The high CDI values obtained in this study disagreed with low CDI values reported by George et al., [29] and Mohammadi et al., [30]. Waste water $\mathrm{CDI}$ values for $\mathrm{Cu}, \mathrm{Zn}, \mathrm{Cd}, \mathrm{Cr}, \mathrm{Ni}$ and $\mathrm{Pb}$ were observed to be higher than the values obtained in stream and well water this may be explained as due to mining activities and the use of the water for the processing of mineral ore.

\subsubsection{Carcinogenic Risk Analysis}

Contaminant $(\mathrm{Pb}, \mathrm{Cr}, \mathrm{Cd}$ and $\mathrm{Ni})$ can potentially increase the risk of cancer in human [30]. Long term exposure to low amounts of heavy metals could, therefore result in many types of cancers.

Carcinogenic risk through ingestion and dermal contacts for $\mathrm{Cd}, \mathrm{Cr}, \mathrm{As}, \mathrm{Pb}, \mathrm{Ni}$ were evaluated to be $7.6 \times 10^{-3}, 3.7 \mathrm{x}$ $10^{-3}, 4.35 \times 10^{-3}$ and $3.6 \times 10^{-5}$, and $2.62 \times 10^{-8}, 1.24 \times 10^{-7}$, $6.12 \times 10^{-3}, 1.26 \times 10^{-4}$, respectively from the mining waste water. The $\mathrm{CR}$ due to dermal contact and $\mathrm{CR}$ due to ingestion for As were within the $1 \times 10^{-6}$, to $1 \times 10^{-4}$ range for carcinogenic risk acceptable by USEPA. While CR due to ingestion for $\mathrm{Cd}, \mathrm{Cr}, \mathrm{Pb}$ and $\mathrm{Ni}$ in mww were above the remedial goal target of $1 \times 10^{-4}$. This is considered as harmful and cancer risk is worrisome. The results of $\mathrm{CR}$ due to ingestion for $\mathrm{Cd}, \mathrm{Cr}$, and $\mathrm{Ni}$ from the first well and stream around the mining site were above the remedial target of $1 \mathrm{x}$ $10^{-4}$ therefore raising carcinogenic concerns for the community around the mining area. Similarly, the values of $\mathrm{CR}$ due to ingestion for $\mathrm{Cd}$ and $\mathrm{Pb}$ in well water 2 was observed to be above the remedial target ranged of $1 \times 10^{-6}$ to $1 \times 10^{-4}$ set by USEPA [17]. From the stream water 2, CR due to ingestion for $\mathrm{Cd}, \mathrm{Cr}$ and $\mathrm{Ni}$ was observed to be also above the remedial target range of $1 \times 10^{-6}$ to $1 \times 10^{-4}$. Among all the studied heavy metals, cadmium and chromium has the highest chance of cancer risks (CR $5.17 \times 10^{-3}$ and $1.8 \times 10^{-3}$ ) and $\mathrm{Pb}$ and $\mathrm{Ni}$ has the lowest chance of risks (CR $1.69 \times 10^{-4}$ and $\left.5.9 \times 10^{-4}\right)$. The results of cancer risks recorded in this present study agree with earlier studies similar to this conducted and reported by George et al., [29] and Mohammadi et al, [30]. The results also show that the carcinogenic risks were found to be higher than the noncarcinogenic risks to the residents through ingestion of water from water bodies around the mining area.

\section{Conclusion}

The well use by the community around the mining area and the stream water within the mining area were contaminated with $\mathrm{Cr}, \mathrm{Cd}$ and $\mathrm{Pb}$ as their concentration were greater than the standard concentration limit set by WHO and NESREA. The decrease metal concentration is in the following order $\mathrm{Pb}>\mathrm{Zn}>\mathrm{Cd}>\mathrm{Cr}>\mathrm{Cu}>\mathrm{Ni}$. This implies that water sources within and around the mining area may not be fit for drinking purposes.

The Chronic Daily Intake (CDI) values for all the heavy metals showed high CDI. The HQs for those exposure pathways of this work decline in the following order: ingestion $>$ dermal adsorption, meaning that ingestion is the dominant pathway of exposure to every receptor. The total values of HI through ingestion and dermal adsorption were obtained to be $218.7,12.54,10.11,9.94,44.02$, and 18.44, $2.12,1.81,1.58,0.45$, respectively. 
The ILCR result of this study showed that $\mathrm{Cr}$ and $\mathrm{Cd}$ has the highest chances of cancer risks with $\mathrm{Pb}$ and $\mathrm{Ni}$ the lowest. It could be concluded that the stream and well water in the study area pose a significant health risk to human as a result of the presence of toxic metals hence the stream and well water should not be used for drinking without adequate treatment. This study has also highlighted the need for further research and regular monitoring, in order to determine the permitted levels of metals in the studied aquifer.

\section{Conflicts of Interest}

There is no competing interest in relation to this manuscript

\section{Acknowledgements}

The Authors are grateful to the authorities of Soil Science Laboratory ABU Zaria for assisting with laboratory facility to analyze the samples. We are further grateful to Professor Rufus Sha'Ato of UAM for his input.

\section{References}

[1] Musa W. O and Tukura B. W (2017). Evaluation of Heavy Metal Concentration in Borehole Water Near Solid Waste Dumpsites. Journal of Natural and Applied Sciences, 5 (2) 143-149.

[2] Onyele, O. G. and Anyanwu E. D. (2017). Occurance and concentration of heavy metals in rural springs in southern Nigeria. Journal of Applied Science and Environmental Management 22 (9): 1473-1478.

[3] Adika A. C, Joshua K. K; Ambrose K. K. and Munyendo L W (2018). The Assessment of bore-hole water quality of Kakamega country Keny. Applied water science 8 (47): 1-8.

[4] He, Z., Shentu, J., Yan, X., Baligar, V. C., Zhang, T., Stoffella, P. J. (2015). Heavy metal contamination of soils sources, indicators and assessment. Journal of Environmental Indicator 9: 17-18.

[5] Muhammad I., Ashirus S., Ibrahim I. D., Salawu K., Muhammad D. T and Muhammad T. A (2013). Determination of Some Heavy Metals in Waste Water and Sediment of Artisamal Gold Local Mining Site of Abare Area in Nigeria. Journal of Environmental Treatment Techniques, 1 (3): 174182.

[6] Eneji, I. S, Rufus, Sha' Ato, and Paul, A. A (2011) An Assessment of heavy metals loading in River Benue in the Makurdi metropolitan Area in central Nigeria. Environmental Monitoring Assessment, 184 (1): 201-207.

[7] Izah, S. C. and Angaye T. C. N (2016) heavy metal concentration in fishes from surface water in Nigeria: potential source of pollutants and mitigation measures. Sky Journal of Biochemistry Research 1 (1): 26-28.

[8] Adesiyan I. M., Johnson M. B., Aladesanmi O. J., Okoh A. I. and Ogunfowokan A. O (2018). Concentrations and Human Health Risk of Heavy metals in Rivers in Southwest Nigeria. Journal of Health and Pollution 8 (19): 1-27.
[9] Aghoghovwa O. A. Miri F. A. and Sylvester C. I. (2018) Impacts of Anthropogenic Activities on heavy metal levels in surface water of Nun River around Gbarantoru and Tombia Towns Bayelsa State, Nigeria. Annals of Ecology and Environmental Science 2 (2): 1-8.

[10] Sekabira K. Origa H. O; Basamba T. A., Mutuma G., Kakudidi E. (2010) Assessment of heavy metal pollution in the urban stream sediments and its tributaries. International Journal of Environmental Science Technology 7 (3) 435-446.

[11] UNEP/OCHA (2010) Lead Pollution and Poisoning Crisis. Environmental Emergency Response Mission Zamfara State, Nigeria. Published in Switzerland by the joint UNEP/OCHA Environmental unit. 10 pages.

[12] Abdulmumin, A. N. Sallau M. S and Majiya M. H. (2014) Heavy metal pollution: the environmental impact of artisanal gold mining in Bagega community, Zamfara Nigeria. Archives of Current Research Journal of Pharmaceutical and Chemical Science, 5 (6): 306-313.

[13] WHO, 2018a Nigeria: Mass lead poisoning from mining activity, Zamfara State, Nigeria 2 Pages.

[14] NPC, 2016 National Population Commission of Nigeria, Abuja.

[15] NBS, 2016 National Bureau of Statistics (documents) 5 pages.

[16] Kamunda C., Mathuthu M., Madhuku M. (2016). Assessment of radiological hazards from gold mine tailings in Gauteng province, South Africa. International Journal of Environmental Research, Public Health, 13: 138-143.

[17] USEPA (1989). Environmental Protection Agency: Risk Assessment guidance for superfund. Vol. I: Human health evaluation manual (Part A). USA, DC, Washington: US EPA, (EPA/540/1-89/002).

[18] WHO 2011 Guideline for drinking water $4^{\text {th }}$ Edition Geneva, Switzerland World Health Organization.

[19] NESREA 2011 Nigeria Environmental Standard and Regulatory Enforcement Agency Guidelines and Standard for Environmental Pollution Control in Nigeria, Abuja, Nigeria.

[20] Nnabo P. N. (2015). Assessment of heavy Metal Contamination of Water Sources from Enyigbu $\mathrm{Pb}-\mathrm{Zn}$ District, Southern Eastern Nigeria. International Journal of Scientific and Technology Research, 4 (09): 187-197.

[21] Yaya L., Xiaoyun yi., Zhi D., Qin W., Hounmei L., and Jie T. (2017). Heavy Metal Concentration and Health Risk Assessment in the vicinity of a Tailing Pond in Guangdong, China. International Journal of Environmental Research and Public Health 14 (12): 1557.

[22] Tadesse M., Tsagaye D, Gima G, (2018). Assessmentr of the level of some physic-chemical parameters and heavy metals of Rebu River in Oronmia Region, Ethiopia MOJ Biology and Medicine, 3 (3) 99-110.

[23] Zamani A. A. Mohammed R. Y. and Abdolhossein P. (2012). Multivate Statistical assessment of heavy metal pollution sources of ground water around a lead/zinc plant. Iranian journal of environmental health science and engineering, 9 (1): 29-39.

[24] WHO, (2018b). Lead poisoning and Global Health observatory regulations and control on lead plant Geneva: World Health Organization. 
[25] Yi-chaun, L., Carries A. D., Antonio, N., James D., Taran, J., Andrew M., Loride R., Donglas T. Lora D., Raymond S. D., and Mathias Y., (2012). Childhood Lead Poisoning Association with Gold Ore processing: a village level investigation Zamfara State Nigeria October-November (2010): environmental Health Perspective 120 (10): 14501455.

[26] Adamu G. K., Muhammad Auwal, Abba A. K. and Halliru J. L. (2015) Assessment of heavy metal in soils and surface water around mines in Jos metropolis Plateau State. International Journal of Multidisciplinary Research and Development 2 (12): 386-389.

[27] Boateng T. K., Opoku F., Akoto O. (2019). Heavy metal contamination assessment of ground water quality: A case study of odi Landfill site, Mumasi. Applied water science 9 (33): 1-15.

[28] USEPA 2010 Risk Assessment Guidance for Superfund Volume I. Human Health Evaluation Manual (Part A). In: Agency USEP, editor. Washington, DC.

[29] George Y. H, David K. E. Joseph K. A. (2015). Distribution and Risk Assessment of Heavy metals in surface water from pristine Environments and Major Mining Areas in Ghana. Journal of Health and Pollution 5 (9): 86-99.

[30] Mohammadi A. A., Zarei A, Majidi S., Ghaderpoury A., Hashepour Y., Saghi M. H. Alinejad A. Yousef M, (2019). Carcinogenic and Non-Carcinogenic Metals Health Risk Assessment of heavy Metal in Drinking water of Khorram Abda, Iran, Methodsx, 6: 1642-1651. 